\title{
Local and regional drivers of headwater streams metabolism: insights from the first AlL collaborative project
}

Ada Pastor ${ }^{1,2, *, *}$, Anna Lupon ${ }^{3, *}$, Lluís Gómez-Gener ${ }^{1, *}$, Tamara Rodríguez-Castillo ${ }^{4, *}$, Meritxell Abril ${ }^{1}$, María Isabel Arce ${ }^{5}$, Ibon Aristi ${ }^{6}$, Maite Arroita ${ }^{6}$, Andrea G. Bravo ${ }^{7}$, Núria de Castro-Català ${ }^{1}$, Rubén del Campo ${ }^{8}$, Joan Pere Casas-Ruiz ${ }^{2}$, Edurne Estévez ${ }^{4}$, Diego Fernández $^{9}$, Mireia Fillol ${ }^{2}$, Lorea Flores ${ }^{10}$, Anna Freixa ${ }^{2,11}$, Pau Giménez-Grau ${ }^{12}$, Alexia María González-Ferreras ${ }^{4}$, Elena Hernández-del Amo ${ }^{11}$, Eduardo J. Martín ${ }^{13}$, Aingeru Martínez $^{6}$, Silvia Monroy ${ }^{6}$, Juanita Mora-Gómez ${ }^{11}$, Carlos Palacin-Lizarbe ${ }^{12}$, Olatz Pereda ${ }^{6}$, Sílvia Poblador ${ }^{1}$, Rubén Rasines-Ladero ${ }^{14}$, Marta Reyes ${ }^{13}$, Pablo Rodríguez-Lozano ${ }^{1,15}$, Celia Ruiz $^{16}$, Isis Sanpera-Calbet ${ }^{1}$, Libe Solagaistua ${ }^{6}$, Irene Tornero ${ }^{11}$ and Núria Catalán ${ }^{2,7, \star}$

${ }^{1}$ Departament de Biologia Evolutiva, Ecologia i Ciències Ambientals, Facultat de Biologia, Universitat de Barcelona, Av. Diagonal, 643, 08028 Barcelona, Spain.

${ }^{2}$ Catalan Institute for Water Research (ICRA), Emili Grahit 101, 17003 Girona, Spain.

${ }^{3}$ Department of Forest Ecology and Management, Swedish University of Agricultural Sciences (SLU), 90183 Umeå, Sweden.

${ }^{4}$ Environmental Hydraulics Institute, Universidad de Cantabria-Avda. Isabel Torres, 15, Parque Científico y Tecnológico de Cantabria, 39011, Santander, Spain.

${ }^{5}$ Leibniz-Institute of Freshwater Ecology and Inland Fisheries (IGB), Müggelseedamm 310, 12587 Berlin, Germany.

${ }^{6}$ Laboratory of Stream Ecology, Department of Plant Biology and Ecology, University of the Basque Country, P.O. Box 644, 48080 Bilbao, Spain.

${ }^{7}$ Limnology/Department of Ecology and Genetics, Uppsala University, Norbyvägen 18D, 75236 Uppsala, Sweden.

${ }^{8}$ Department of Ecology and Hydrology, Faculty of Biology, Regional Campus of International Excellence “Campus Mare Nostrum”, University of Murcia, Campus de Espinardo, 30100 Murcia, Spain.

${ }^{9}$ Institute for Environmental Sciences, University Koblenz-Landau, Fortstraße 776829 Landau, Germany.

${ }^{10}$ INRA, UMR 1224, Ecologie Comportementale et Biologie des Populations de Poissons, Aquapôle, quartier Ibarron, 64310 Saint-Pée sur Nivelle, France.

${ }^{11}$ Institute of Aquatic Ecology, Facultat de Ciències, Universitat de Girona, Campus Montilivi s/n,17071 Girona, Spain.

${ }^{12}$ Centre for Ecological Research and Forestry Applications (CREAF), 08193 Cerdanyola del Vallès, Spain.

${ }^{13}$ Swiss Federal Institute of Aquatic Science and Technology (EAWAG), 8600, Dübendorf, Switzerland.

${ }^{14}$ IMDEA Water Institute, Av. Punto Com, nº 2, Scientific Technological Park of the University of Alcalá, 28805 Alcalá de Henares, Spain.

${ }^{15}$ Department of Environmental Science, Policy, and Management, University of California, Berkeley, California.

${ }^{16}$ IMDEA The National Museum of Natural Sciences (MNCN-CSIC), José Gutiérrez Abascal 2, 28006 Madrid, Spain.

* These authors contributed equally to the development of this work. The rest of the authors are listed in alphabetical order.

* Corresponding author: apastor@icra.cat

Received: 04/10/16

Accepted: 09/01/17

\section{ABSTRACT}

Local and regional drivers of headwater streams metabolism: insights from the first AIL collaborative project 
Streams play a key role in the global biogeochemical cycles, processing material from adjacent terrestrial systems and transporting it downstream. However, the drivers of stream metabolism, especially those acting at broad spatial scales, are still not well understood. Moreover, stream metabolism can be affected by hydrological changes associated with seasonality, and thus, assessing the temporality of metabolic rates is a key question to understand stream function. This study aims to analyse the geographical and temporal patterns in stream metabolism and to identify the main drivers regulating the wholeecosystem metabolic rates at local and regional scales. Using a coordinated distributed experiment, we studied ten headwaters streams located across five European ecoregions during summer and fall 2014. We characterized the magnitude and variability of gross primary production (GPP) and ecosystem respiration (ER) with the open-channel method. Moreover, we examined several climatic, geographical, hydrological, morphological, and physicochemical variables that can potentially control stream metabolic rates. Daily rates of stream metabolism varied considerately across streams, with GPP and ER ranging from 0.06 to $4.33 \mathrm{~g} \mathrm{O}_{2} \mathrm{~m}^{-2} \mathrm{~d}^{-1}$ and from 0.72 to $14.20 \mathrm{~g} \mathrm{O}_{2} \mathrm{~m}^{-2} \mathrm{~d}^{-1}$, respectively. All streams were highly heterotrophic $(\mathrm{P} / \mathrm{R}<1)$, except the southernmost one. We found that the drier climates tended to have the highest GPP, while humid regions presented the highest ER. Between the sampling periods no statistical differences were found. Partial-least squares models (PLS) explained $\sim 80 \%$ of the variance in GPP and ER rates across headwater streams and included both local and regional variables. Rates of GPP varied primarily in response to the local variables, such as streambed substrate and stream water temperature. In contrast, regional variables, such as the mean annual temperature or the land use of the catchment, had more relevance to explain ER. Overall, our results highlight that stream metabolism depends on both local and regional drivers and show the positive experience of a young network of researchers to assess scientific challenges across large-scale geographic areas.

Key words: Gross primary production, ecosystem respiration, functioning, ecoregions, season, coordinated distributed experiment.

\section{RESUMEN}

Controles locales y regionales del metabolismo en ríos de cabecera: aportaciones del primer proyecto colaborativo de la AIL

Los ecosistemas fluviales tienen un papel relevante en los ciclos biogeoquímicos globales, ya que procesan el material de la cuenca y lo transportan río abajo. Sin embargo, los factores que afectan al metabolismo, especialmente aquellos que actúan en una escala espacial más amplia, todavía no se conocen completamente. Además, el metabolismo fluvial puede variar a causa de cambios hidrológicos relacionados con la estacionalidad; lo que también hace importante incluir la variabilidad temporal para entender el funcionamiento de los ríos. Mediante el uso de un experimento distribuido y coordinado, estudiamos diez ríos de cabecera localizados a lo largo de cinco ecoregiones europeas durante verano y otoño del 2014. Se midió la magnitud y la variabilidad de la producción primaria bruta (PPB) y la respiración ecosistémica (RE) mediante el método de canal abierto. Así mismo, se examinaron los factores climáticos, hidrológicos y físico-químicos que potencialmente pueden afectar las tasas metabólicas fluviales. Las tasas diarias de metabolismo fluvial variaron considerablemente entre ríos, con valores de PPB de entre 0.06 a $4.33 \mathrm{~g} \mathrm{O}_{2} \mathrm{~m}^{-2} \mathrm{dia}^{-1}$, y de RE de entre 0.72 a $14.20 \mathrm{~g} \mathrm{O}_{2} \mathrm{~m}^{-2}$ día ${ }^{-1}$. Todos los ríos fueron altamente heterotróficos $(P / R<1)$, excepto el río más meridional. Se observó que los climas secos tendían a tener mayor PPB y las regiones húmedas tendían a tener una mayor RE. No se encontraron diferencias estadísticas entre los períodos de estudio. Los modelos de regresión de mínimos cuadrados parciales (PLS) explicaron $~ 80 \%$ de la varianza de PPB y RE para los ríos estudiados. Las tasas de PPB variaron principalmente con factores locales como el sustrato del lecho del río y la temperatura del agua. En cambio, las tasas de RE estuvieron estrechamente relacionadas con factores regionales, como la temperatura media anual y los impactos en la cuenca. En conjunto, nuestros resultados resaltan la necesidad de incluir la escala local y regional en el estudio del metabolismo fluvial y muestran la experiencia positiva de una red coordinada de jóvenes investigadores para lograr retos científicos de amplia escala geográfica.

Palabras clave: Producción primaria bruta, respiración ecosistémica, funcionamiento, ecoregión, estación, un experimento distribuido y coordinado.

\section{INTRODUCTION}

Stream metabolism is a central descriptor of stream energy exchange and functioning that includes both gross primary production (GPP) and ecosystem respiration (ER) (Odum, 1956; Hynes,
1963; Hall, 1972). These two interrelated processes fix (GPP) and mineralize (ER) organic carbon (C), and thus, are important indicators of energy sources for aquatic food-webs (Woodwell $\&$ Whittaker, 1968). Moreover, the balance between these two processes indicates the degree of 
dependence of the system on subsidies from the adjacent terrestrial ecosystems (Cole \& Caraco, 2001; Hotchkiss et al., 2015). Thus, unraveling the magnitude and drivers of metabolism in streams is fundamental to understand their ecosystem functioning as well as to disentangle the role they play in the continental carbon cycle.

Metabolic activity in streams can be influenced by local variables such as light availability (Hill et al., 1995; Lupon et al., 2016), stream water temperature (Denicola, 1996; Demars et al., 2011), nutrient concentration (Guasch et al., 1995, Yates et al., 2013), organic matter quantity and quality (Webster \& Meyer 1997; Bernhard et al., 2002) or streambed substrate (Mulholland et al., 1997; Clapcott et al., 2010). Likewise, regional variables (i.e. acting at larger geographical scales and usually over longer time periods) such as climate (Mulholland et al., 2001), land use (Bernot et al., 2010; von Schiller et al., 2008; Young et al., 2008), vegetation type (Dodds et al., 2015) and catchment topography (Hoellein et al., 2013) can also affect GPP and ER.

The use of regionalization frameworks such as biomes or ecoregions provides an easy and powerful way to examine the influence of these regional variables on the ecosystem functioning (Knapp \& Smith, 2001; Soranno et al., 2014). However, teasing the relative importance of local variables apart from that of those operating at regional scales is not straightforward, because performing empirical inter-site studies at large spatial scales is usually complex and tends to be associated to elevated costs (Fraser et al., 2013). So far, the few existing inter-regional comparisons of stream metabolism rise contradictory results. Sinsabaugh (1997) and Mulholland et al. (2001) showed that the daily metabolic rates varied across climatic regions of North America, with higher GPP rates occurring in arid opencanopy streams and higher ER rates in warm areas with high nutrient concentrations. Conversely, Bernot et al. (2010) did not find any climatic dependence of ER among 72 streams comprising eight climatic regions across the United States. These contrasting results emphasize that our knowledge of how stream metabolism changes over spatial scales is still far from complete.

In addition to the regional variability, metabolism can greatly vary over time due to changes in catchment hydrology (Young \& Huryn, 1996),

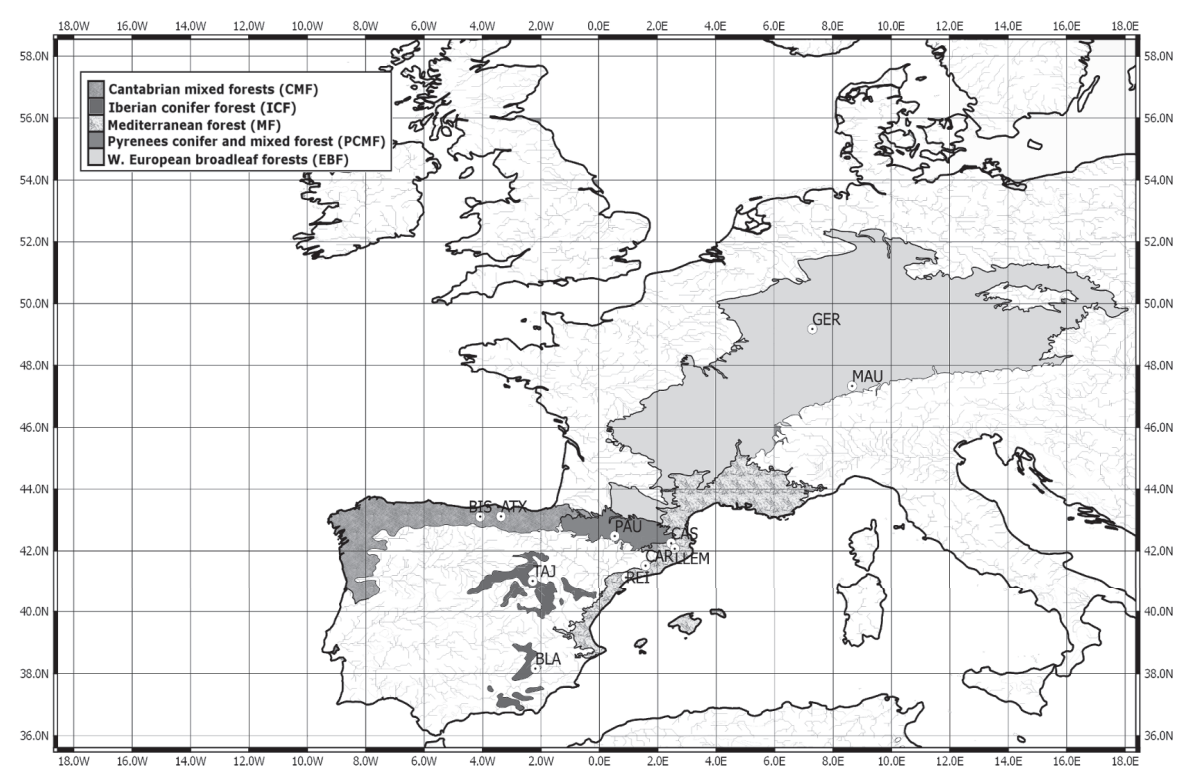

Figure 1. Location of the ten sampling sites and their corresponding ecoregions. Localización de los diez puntos de muestreo y sus correspondientes ecorregiones. 
terrestrial organic matter supply (Acuña et al., 2004), light availability (Roberts et al., 2007) and in-stream community composition (Burrows et $a l ., 2015)$. The magnitude of these seasonal fluctuations can vary from region to region and may alter the drivers of the metabolic processes. In particular, high flow events, and especially those occurring short-after long dry periods, may exert a strong impact on ecosystem metabolism. Despite the fact that these events are predicted to increase in the future due to global change (Field et al. 2014), most of the inter-sites comparisons do not take into account the potential effect of seasonality and terrestrial inputs variability on metabolic rates (e.g. Bernot et al., 2010; Mulholland et al., 2001).

The objective of this study was to investigate the relative importance of local and regional drivers controlling the metabolic activity (GPP and ER) of headwater streams across five ecoregions during two differentiated temporal periods (summer and fall). To address this goal, we used a coordinated distributed experiment among early-career limnologists (DOMIPEX project). We hypothesized that metabolic rates will vary across regions because of their contrasted climatic and biogeographic gradients. Specifically, we expected GPP to be higher in those streams draining warm ecoregions with low canopy cover,while ER rates would increase in humid, forested regions. Furthermore, we anticipated that metabolic rates would be higher in fall as a result of storm flows and increased organic matter and nutrient inputs from the catchment.

\section{MATERIALS AND METHODS}

\section{The setup: a coordinated distributed experiment}

The first call for collaborative projects of the Iberian Association of Limnology (AIL) gathered together 42 early-career researchers of this association. The DOMIPEX project was structured as a coordinated distributed experiment, allowing the standardization of methodologies across temporal and spatial scales (Fraser et al., 2013). Groups of one to seven researchers were established and headwater streams across midand southern Europe were selected based on the geographic distribution of the researchers. The geographically dispersed structure of the participants strongly reduced transport costs and facilitated the compilation of previous information about the study sites.

\section{Study sites and sampling campaigns}

A total of 10 headwater stream reaches comprising five ecoregions (sensu Olson et al., 2001; www.worldwildlife.org/science) were selected to

Table 1. Regional characteristics of the studied stream reaches. Características regionales de los ríos estudiados.

\begin{tabular}{|c|c|c|c|c|c|c|c|c|c|c|}
\hline \multicolumn{11}{|c|}{ REGIONAL CHARACTERISTICS } \\
\hline \multirow[t]{2}{*}{$\begin{array}{l}\text { Stream } \\
\text { code }\end{array}$} & \multirow[t]{2}{*}{ Ecoregion } & \multirow[t]{2}{*}{$\begin{array}{l}\text { UTM } \\
\text { Zone }\end{array}$} & \multicolumn{2}{|c|}{$\begin{array}{c}\text { UTM } \\
\text { Coordinates }(\mathrm{m})\end{array}$} & \multirow[t]{2}{*}{$\begin{array}{c}\text { Mean Annual } \\
\text { Precipitation }(\mathrm{mm})\end{array}$} & \multirow[t]{2}{*}{$\begin{array}{c}\text { Mean Annual } \\
\text { Temperature }\left({ }^{\circ} \mathrm{C}\right)\end{array}$} & \multirow[t]{2}{*}{$\begin{array}{l}\text { Catchment } \\
\text { Area }\left(\mathrm{km}^{2}\right)\end{array}$} & \multicolumn{3}{|c|}{$\begin{array}{c}\text { Catchment Land } \\
\text { Uses }(\%)\end{array}$} \\
\hline & & & $x$ & $y$ & & & & Forest & Grassland & Impacted \\
\hline BIS & CMF & 30 & 412418 & 4774121 & 1075 & 12 & 17 & 49 & 48 & 3 \\
\hline TAJ & ICF & 30 & 560715 & 4542205 & 592 & 11 & 62 & 4 & 60 & 36 \\
\hline BLA & ICF & 30 & 570717 & 4224246 & 472 & 13 & 11 & 0 & 91 & 9 \\
\hline CAR & MF & 31 & 884118 & 4607471 & 506 & 14 & 64 & 52 & 23 & 25 \\
\hline CAS & MF & 31 & 952144 & 4692193 & 974 & 13 & 1 & 92 & 5 & 3 \\
\hline REI & MF & 31 & 830429 & 4562058 & 538 & 16 & 23 & 36 & 50 & 14 \\
\hline LLEM & MF & 31 & 963629 & 4672973 & 1009 & 14 & 28 & 93 & 2 & 5 \\
\hline PAU & PCMF & 31 & 791945 & 4709527 & 1184 & 9 & 6 & 38 & 61 & 1 \\
\hline MAU & $\mathrm{EBF}$ & 32 & 1380940 & 5309031 & 1185 & 10 & 1.4 & 31 & 23 & 44 \\
\hline GER & EBF & 32 & 1250705 & 5499101 & 918 & 15 & 6 & 60 & 1 & 40 \\
\hline
\end{tabular}

$\mathrm{CMF}=$ Cantabrian mixed forest, ICF = Iberian conifer forest, MF = Mediterranean forest, PCMF = Pyrenees conifer and mixed forest and EBF = European broad-leaf forest. 
measure stream metabolism (Fig. 1; Table 1). In particular, one reach corresponded to Cantabrian mixed forest (CMF), two reaches to Iberian conifer forest (ICF), four reaches to Mediterranean forest $(\mathrm{MF})$, two reaches to European broad-leaf forest (EBF) and one reach to Pyrenees conifer and mixed forest (PCMF). Each stream reach was sampled during summer and fall 2014, with the exception of BLA, MAU, and GER, which were not sampled during fall due to logistical problems.

These ecoregions comprise a wide geographical distribution from southern Iberian Peninsula to southern Germany (Fig. 1), resulting in a large variability of climatic and biogeographic conditions (See Table S2, available at www. limnetica.com). Mediterranean ecoregions, i.e. MF and ICF, are characterized by dry summers and mild winters. CMF and PCMF are situated between the Eurosiberian and Mediterranean regions of Europe. CMF has warm Atlantic conditions with mild temperatures and high precipitation, whereas PCFM is characterized by a colder weather. Finally, temperate climate and moist conditions predominate in EBF along the year.

The study sites were located in headwater streams, draining small catchments $\left(<64 \mathrm{~km}^{2}\right.$ ha; Table 1) and with flows lower than $31 \mathrm{~L} / \mathrm{s}$ (Table 2). Moreover, all selected sites had from moderate to high habitat diversity (Fluvial Habi- tat Index $[\mathrm{IHF}]=50-80 ;$ Pardo et al., 2004) and exhibited a relatively structured and diverse riparian zone (Riparian Forest Quality index [QBR] $=55-95$; Munné et al., 2003). Streams were homogeneous and not affected by water entries from WWTP or tributaries.

\section{Characterization of regional and local controls of stream metabolism}

Regional variables. Six regional variables were selected and obtained from a Virtual Watershed Approach (Table 3). Synthetic River Network was delineated using a 10-m digital elevation model (DEM) developed by the National Geographic Institute using the NestStream software (Álvarez-Cabria et al. 2016, Benda et al. 2007). Climatic variables, included mean annual catchment precipitation (MAP; mm) and mean annual catchment temperature (MAT; ${ }^{\circ} \mathrm{C}$ ), were obtained for the 1980-2006 period from the Integrated System for Rainfall-Runoff Modelling (SIMPA; $1 \mathrm{~km} \times 1 \mathrm{~km}$ grid map), except for GER and MAU reaches, that were obtained from the Deutscher Wetterdienst monitoring agency and the Swiss Federal Office of Meteorology and Climatology (SwissMetNet), respectively. Catchment area (Area; ha) was derived from the 10-m DEM. Land use was obtained from the Occupation Information System of Soil in Spain.

Table 2. Local characteristics of the studied stream reaches for summer and fall. Características locales de los ríos estudiados en verano y otoño.

\begin{tabular}{|c|c|c|c|c|c|c|c|c|c|c|c|c|c|c|c|}
\hline \multicolumn{16}{|c|}{ LOCAL CHARACTERISTICS } \\
\hline \multirow[t]{2}{*}{$\begin{array}{l}\text { Stream } \\
\text { code }\end{array}$} & \multirow[t]{2}{*}{$\begin{array}{c}\text { Stream } \\
\text { slope }(\%)\end{array}$} & \multicolumn{2}{|c|}{ Coarse: fine* } & \multicolumn{2}{|c|}{$\begin{array}{c}\text { Discharge } \\
(\mathrm{L} / \mathrm{s})\end{array}$} & \multicolumn{2}{|c|}{$\begin{array}{c}\text { Temperature } \\
\left({ }^{\circ} \mathrm{C}\right)\end{array}$} & \multicolumn{2}{|c|}{$\begin{array}{l}\text { Conductivity } \\
(\mu \mathrm{S} / \mathrm{cm})\end{array}$} & \multicolumn{2}{|l|}{$\mathrm{pH}$} & \multicolumn{2}{|c|}{$\begin{array}{c}\text { DOC } \\
(\mathrm{mg} / \mathrm{L})\end{array}$} & \multicolumn{2}{|c|}{$\begin{array}{c}\text { DIN } \\
(\mu \mathrm{g} \mathrm{N} / \mathrm{L})\end{array}$} \\
\hline & & Summer & Fall & Summer & Fall & Summer & Fall & Summer & Fall & Summer & Fall & Summer & Fall & Summer & Fall \\
\hline BIS & 2.9 & n.a. & n.a. & 14.4 & 25.8 & 15.4 & 13.4 & 353 & 337 & 8.4 & 8.2 & 0.8 & 1.1 & 547 & 512 \\
\hline TAJ & 0.7 & 0.8 & 0.8 & 23.9 & 24.9 & 14.5 & 12.7 & 594 & 632 & 7.8 & 7.4 & 1.1 & 0.9 & 3196 & 2856 \\
\hline BLA & 2.5 & n.a. & n.a. & 9.1 & n.a. & 23.1 & n.a. & 481 & n.a. & 8.5 & $\mathrm{Na}$ & 1.9 & n.a. & 527 & n.a. \\
\hline CAR & 0.5 & 1.1 & 0.9 & 7.5 & 9.7 & 19.6 & 10.3 & 967 & 1060 & 7.7 & 7.7 & 1.9 & 1.9 & 2152 & 5747 \\
\hline CAS & 6.2 & 4.6 & 3.6 & 14.2 & 7.4 & 18.2 & 7.4 & 500 & 556 & 8.1 & 8.1 & 2.3 & 1.4 & 169 & 445 \\
\hline REI & 2.9 & 8.3 & 7.0 & 18.3 & 5.5 & 20.1 & 16.5 & 781 & 728 & 8.1 & 8.0 & 2.4 & 1.6 & 3135 & 1288 \\
\hline LLEM & 1.3 & 5.3 & 7.3 & 19.3 & 11.2 & 17.5 & 11.8 & 515 & 512 & 7.9 & 8.0 & 1.0 & 1.2 & 927 & 2372 \\
\hline PAU & 4.5 & 7.7 & 10.5 & 30.8 & 14.1 & 11.4 & 7.1 & 359 & 439 & 8.3 & 8.5 & 2.9 & 1.8 & 178 & 279 \\
\hline MAU & 7.3 & 24 & n.a. & 3.8 & n.a. & 15.5 & n.a. & 468 & n.a. & 8.2 & n.a. & 2.1 & n.a. & 9480 & n.a. \\
\hline GER & 4.9 & 0.4 & n.a. & 5.5 & n.a. & 12.6 & n.a. & 208 & n.a. & 7.6 & n.a. & 2.7 & n.a. & 1616 & n.a. \\
\hline
\end{tabular}

n.a. stands for not available data. * Ratio of coarse to fine streambed inorganic material. 
(SIOSE; 1:25000) for all streams except GER and MAU. Land use covers for GER and MAU streams were obtained from Corine Land Cover 2006 (http://www.eea.europa.eu/data-and-maps) and the Swiss land use data (www.landusestat.admin.ch), respectively. We quantified the land use as a continuous variable at the catchment scale using the ratio between the percentages of impacted (i.e. agricultural and urban) and reference (i.e. forests, scrubs and grassland) land uses (Impacted:Reference; Tables 1 and 3).

Three additional climatic and hydrological variables were obtained from different public data bases (AEMET, DeutscherWetterdienst and SwissMetNet) to characterize both sampling periods (summer and fall). Mean air temperature (T30d; ${ }^{\circ} \mathrm{C}$ ) and total precipitation $(\mathrm{P} 30 \mathrm{~d} ; \mathrm{mm})$ during the month prior to each field campaign were used as proxies of antecedent climatic conditions. We further calculated the number of rainless days before each field campaign (ante- cedent dry period -ADP-; days) as an indicator of water transport through the catchment. Regional variables are expected to act not only at broader spatial but also temporal scales than local variables.

Local variables. Ten local controls of stream metabolism, comprising hydrological, physical, morphological, and chemical properties of each stream reach were measured in situ in summer and fall 2014 (Table 3).

For each field campaign, stream flow $(\mathrm{Q} ; \mathrm{L} / \mathrm{s})$ and stream water velocity $(\mathrm{V} ; \mathrm{m} / \mathrm{s})$ were measured using the "slug" chloride addition technique (Gordon et al., 2004). Moreover, water temperature $\left(\mathrm{Tw} ;{ }^{\circ} \mathrm{C}\right), \mathrm{pH}$, and conductivity $(\mathrm{EC}$; $\mu \mathrm{S} / \mathrm{cm}$ ) from the stream water column were measured in situ with hand-probes. Light availability was inferred from visual estimates of the percentage of the stream channel shaded by riparian canopy in five spots along the reach (Pardo et al., 2004).

Table 3. List of the regional and local factors analysed in partial least square (PLS) models. Lista de factores regionales y locales analizados en los modelos de regresión de mínimos cuadrados parciales (PLS).

\begin{tabular}{|c|c|c|}
\hline Variable & Description & Units \\
\hline \multicolumn{3}{|l|}{ Response variables } \\
\hline GPP & Gross primary production & $\mathrm{g} \mathrm{O}_{2} \mathrm{~m}^{-2} \mathrm{~d}^{-1}$ \\
\hline ER & Ecosystem respiration & $\mathrm{g} \mathrm{O}_{2} \mathrm{~m}^{-2} \mathrm{~d}^{-1}$ \\
\hline \multicolumn{3}{|c|}{ Regional predictor variables } \\
\hline MAP & Mean annual catchment precipitation (1980-2006) & $\mathrm{mm}$ \\
\hline MAT & Mean annual catchment temperature (1980-2006) & ${ }^{\circ} \mathrm{C}$ \\
\hline P30d & Accumulated precipitation during the month prior each field campaign & $\mathrm{mm}$ \\
\hline T30d & Mean air temperature during the month prior to each field campaign & ${ }^{\circ} \mathrm{C}$ \\
\hline $\mathrm{ADP}$ & $\begin{array}{l}\text { Antecedent dry period (days without precipitation }(<0.05 \mathrm{~mm}) \text { before the } \\
\text { campaign) }\end{array}$ & days \\
\hline Area & Catchment area & $\mathrm{km}^{2}$ \\
\hline Impacted: Reference & $\begin{array}{l}\text { Ratio between the percentage of human impacted (agricultural and urban use) and } \\
\text { non- impacted catchment surface area }\end{array}$ & \\
\hline \multicolumn{3}{|c|}{ Local predictor variables } \\
\hline Slope & Mean slope of the stream reach & $\%$ \\
\hline Q & Stream discharge & $\mathrm{L} / \mathrm{s}$ \\
\hline $\mathrm{D}$ & Mean stream reach depth & $\mathrm{m}$ \\
\hline $\mathrm{Tw}$ & Stream water temperature & ${ }^{\circ} \mathrm{C}$ \\
\hline $\mathrm{pH}$ & Stream water $\mathrm{pH}$ & \\
\hline EC & Stream water electrical conductivity & $\mu \mathrm{S} / \mathrm{cm}$ \\
\hline DOC & Dissolved organic carbon concentration & $\mathrm{mg} / \mathrm{L}$ \\
\hline DIN & Total dissolved nitrogen concentration & $\mu \mathrm{g} \mathrm{N} / \mathrm{L}$ \\
\hline Canopy cover & Average reach canopy cover & $\%$ \\
\hline Coarse:Fine & Ratio between the percentage of coarse and fine streambed inorganic material & \\
\hline
\end{tabular}


Stream morphology was characterized by measuring the stream slope $(\mathrm{S} ; \%)$, the stream water depth $(\mathrm{D} ; \mathrm{m})$ and the streambed composition for each stream reach. Stream slope was calculated as the relative change in stream elevation between the beginning and the end of each reach. Stream water depth was calculated by averaging the water column depth measured at $20-\mathrm{cm}$ intervals in five transects along the stream reach. Streambed composition was measured together with water depth and was quantified as the ratio between the percentages of coarse $(\varnothing>$ $2 \mathrm{~mm}$ ) and fine $(\varnothing<2 \mathrm{~mm})$ substrates (Pardo $e t$ al., 2004).

Finally, water samples (three replicates) were collected, filtered $(0.7 \mu \mathrm{m} \mathrm{GF} / \mathrm{F}$ filters; Whatman, Maidstone, UK), and analyzed for dissolved inorganic nitrogen (DIN; $\mu \mathrm{g} / \mathrm{L})$ and dissolved organic carbon (DOC; mg/L) concentrations. All water samples were frozen and sent to analyze to the same laboratory facilities. DIN was calculated as the sum of ammonium and nitrate concentrations. Ammonium was manually analyzed by the salicylate-nitropruside method (Baethgen and Alley 1989) using a PharmaSpec UV-1700 spectrophotometer (Shimadzu Corporation, Kyoto, Japan). Nitrate was analyzed by ionic chromatography on a Metrohm IC system (883 Basic IC Plus) fitted with a Metrosep A Supp 4/5 guard column and a Metrosep A Supp 5 analytical column. DOC was determined by oxidative combustion infra-red analysis using a Shimadzu TOC-VS (Shimadzu Corporation, Kyoto, Japan).

\section{Metabolism calculations}

We calculated whole stream metabolism by using the open-channel method (Odum 1956), which is based on the premise that the change in dissolved oxygen concentration over time $\left(\triangle \mathrm{DO} ; \mathrm{g} \mathrm{O}_{2} \mathrm{~m}^{-3}\right.$ $\left.\mathrm{d}^{-1}\right)$ is caused by the GPP, ER, and gas exchange with the atmosphere $\left(\mathrm{F}_{\mathrm{O}_{2}} ; \mathrm{g} \mathrm{O}_{2} \mathrm{~m}^{-3} \mathrm{~d}^{-1}\right)$ :

$$
\Delta \mathrm{DO}=\mathrm{GPP}-\mathrm{ER} \pm \mathrm{F}_{\mathrm{O}_{2}}
$$

Consequently, whole stream net ecosystem production (NEP, $\mathrm{g} \mathrm{O}_{2} \mathrm{~m}^{-3} \mathrm{~d}^{-1}$ ) was estimated as:

$$
\mathrm{NEP}=\Delta \mathrm{DO} \pm \mathrm{F}_{\mathrm{O}_{2}}
$$

For each site and period, $\triangle \mathrm{DO}$ was calculated as the time differences between dissolved oxygen concentrations ( $\mathrm{DO} ; \mathrm{mg} \mathrm{O}_{2} / \mathrm{m}^{3}$ ) recorded at 30-min intervals for 24-48 hours using optical or polarographic oxygen sensors (See Fig. S1 and Fig. S2 daily $\mathrm{O}_{2}$ curves, available at www. limnetica.com).

$\mathrm{F}_{\mathrm{O}_{2}}$ was calculated as

$$
\mathrm{F}_{\mathrm{O}_{2}}=\mathrm{K}_{\mathrm{O}_{2}}\left(\mathrm{O}_{2, \text { sat }}-\mathrm{O}_{2, \mathrm{w}}\right) \text {, }
$$

where $\mathrm{K}_{\mathrm{O}_{2}}$ is the specific reaeration coefficient of oxygen $\left(\mathrm{d}^{-1}\right), \mathrm{O}_{2 \text {, w }}$ is the measured DO concentration in water, and $\mathrm{O}_{2}$, sat is the DO concentration in atmospheric equilibrium calculated at each time step from temperature $\left({ }^{\circ} \mathrm{C}\right)$ and corrected for barometric pressure $(\mathrm{mmHg})$ (Benson \& Krause, 1984). We estimated the standardized gas transfer velocity for $\mathrm{O}_{2}$ at $17.5^{\circ} \mathrm{C}\left(k_{600} ; \mathrm{m} / \mathrm{d}\right)$ by applying the equation (2) of Raymond et al. (2012):

$$
\begin{aligned}
k_{600} & =5937 \times\left(1-2.54 \times F r^{2}\right) \times \\
& \times(V \times S)^{0.89} \times D^{0.58}
\end{aligned}
$$

where $V(\mathrm{~m} / \mathrm{s})$ is the mean reach water velocity, $S$ $(\mathrm{m} / \mathrm{m})$ is the reach slope, $D(\mathrm{~m})$ is the mean reach depth and $\mathrm{Fr}$ is the Froude number $(\mathrm{Fr}=\mathrm{V} /(\mathrm{g} \times$ $D)^{0.5}$ ), with $g$ being the gravitational acceleration). The $k_{600}$ was transformed then to $K_{\mathrm{O}_{2}}$ following:

$$
K_{\mathrm{O}_{2}}=\frac{k_{600} \times 1.024^{T-17.5}}{D}
$$

where $T$ is the stream reach water temperature (in ${ }^{\circ} \mathrm{C}$ ). Sensitivity of ER, GPP and NEP estimates to variation in $k_{600}$ was examined at various levels of $k_{600}$ percent change $( \pm 1 \%, \pm 5 \%$ and $\pm 25 \%)$ and results are included in the appendix (See Table S4, available at www.limnetica.com).

Average night-time respiration (ANR, $\mathrm{g} \mathrm{O}_{2}$ $\mathrm{m}^{-3} \mathrm{~h}^{-1}$ ) was calculated as the mean NEP during the night hours, extrapolating it to 24 hours to estimate ER $\left(\mathrm{g} \mathrm{O}_{2} \mathrm{~m}^{-3} \mathrm{~d}^{-1}\right)$. Therefore, we as- 
sumed that instantaneous ER was constant during the entire day (Bott, 2006). GPP $\left(\mathrm{g} \mathrm{O}_{2} \mathrm{~m}^{-3} \mathrm{~d}^{-1}\right)$ was calculated as the sum of diurnal NEP and diurnal respiration (ANR extrapolated to light period). Production to respiration ratio $(\mathrm{P} / \mathrm{R})$ was calculated as the ratio between GPP and ER. Finally, we multiplied GPP, ER, and NEP by the mean reach depth to obtain areal estimates $\left(\mathrm{g} \mathrm{O}_{2}\right.$ $\left.\mathrm{m}^{-2} \mathrm{~d}^{-1}\right)$. During summer at REI stream, it was only possible to measure DO at night, and thus, GPP and NEP were not calculated.

\section{Statistical analysis}

We examined whether regional and local variables and metabolic rates (GPP and ER) statistically differed between periods by performing a paired t-test. In all cases, residuals were tested for normality using a Shapiro-Wilk test, and homogeneity of variance was examined visually by plotting the predicted and residual values. In those cases that the normality assumption was unmet, data was log transformed. The collaborative nature of the experiment led to an uneven distribution of the sites within regions, which prevents us from applying statistical tests for region as factor. Spearman's correlation tests were computed to examine (i) the correlation between regional and local variables and (ii) the association between metabolic rates. The differences were considered statistically significant when $p<0.05$.

We built partial-least squares regression models (PLS) to identify the potential drivers of GPP and ER rates. The PLS analysis identifies the relationship between independent (X; not transformed regional and local variables described in Table 3) and dependent (Y; log-transformed GPP and ER) data matrices through a linear, multivariate model; and produces latent variables (i.e. PLS loadings) representing the combination of $\mathrm{X}$ variables that best describe the distribution of observations in 'Y space' (Eriksson et al. 2006). For each Y-variable, the best PLS model was selected by iteratively removing $\mathrm{X}$-variables with the lowest importance on the projection in order to maximize the goodness of fit $\left(\mathrm{R}^{2} \mathrm{Y}\right)$ and the predictive ability $\left(\mathrm{Q}^{2} \mathrm{Y}\right)$ of the model. In each case, $\mathrm{Q}^{2} \mathrm{Y}$ was determined by comparing modeled and actual $\mathrm{Y}$ observations through an iterative, cross-validation process. We evaluated the influence of each X-variable by using variable importance on the projection (VIP) scores, calculated as the sum of square of the PLS weights across all components. Variables with high influence on metabolic rates were considered those having VIP $>1$, while variables with moderate and low influence were those with $0.8<$ VIP $<1$ and VIP $<0.8$, respectively (Eriksson et al., 2006). Finally, we illustrate the relationship between GPP and ER and the most influential local and regional drivers (i.e. highest VIP scores obtained in the PLS model) using simple linear regression models. We carried out PLS models in XL-STATS software (XL-STATS 2015.2.01, Addinsoft SRAL, Germany). All other statistical tests were performed in R 3.2.2 (R Core Team 2015).

\section{RESULTS}

\section{Regional and local variables across regions and periods}

Climatic and topographic conditions showed a great variation in the studied streams (Table 1). MAP ranged from $472 \mathrm{~mm}$ (BLA) to $1184 \mathrm{~mm}$ (PAU), MAT from $9{ }^{\circ} \mathrm{C}$ (PAU) to $16{ }^{\circ} \mathrm{C}$ (REI) and catchment area from 1 to $62 \mathrm{~km}^{2}$ (Table 1 ). The land use distribution on the catchment varied from $>90 \%$ forest (CAS and LLEM) to $>90 \%$ grasslands and scrubland (BLA); and four catchments had a notable ( $\geq 25 \%$ of agricultural and urban) human influence (MAU, TAJ, GER, and CAR).

Regarding the local variables (Table 2; also see Table S1 available at www.limnetica.com), stream flow (3.8-30.8 L/s), channel slope $(0.5-$ $7.3 \%)$ and water depth $(0.06-0.18 \mathrm{~m})$ varied one order of magnitude across stream reaches. All reaches had predominantly coarse sediments or bedrock (>50\%), except GER, which streambed was composed by $93 \%$ of fine sediments. Furthermore, stream water properties varied widely across streams and periods, with Tw ranging from $7{ }^{\circ} \mathrm{C}$ (PAU in fall) to $23{ }^{\circ} \mathrm{C}$ (BLA in summer), 
and EC from $208 \mu \mathrm{S} / \mathrm{cm}$ (GER in summer) to $1060 \mu \mathrm{S} / \mathrm{cm}$ (CAR in fall). There were small differences in $\mathrm{pH}$ (7.4-8.5) and DOC concentrations
(0.8-2.9 mg/L), while DIN concentrations (169$9480 \mu \mathrm{g} \mathrm{N} / \mathrm{L}$ ) varied almost two orders of magnitude across streams (Table 2).
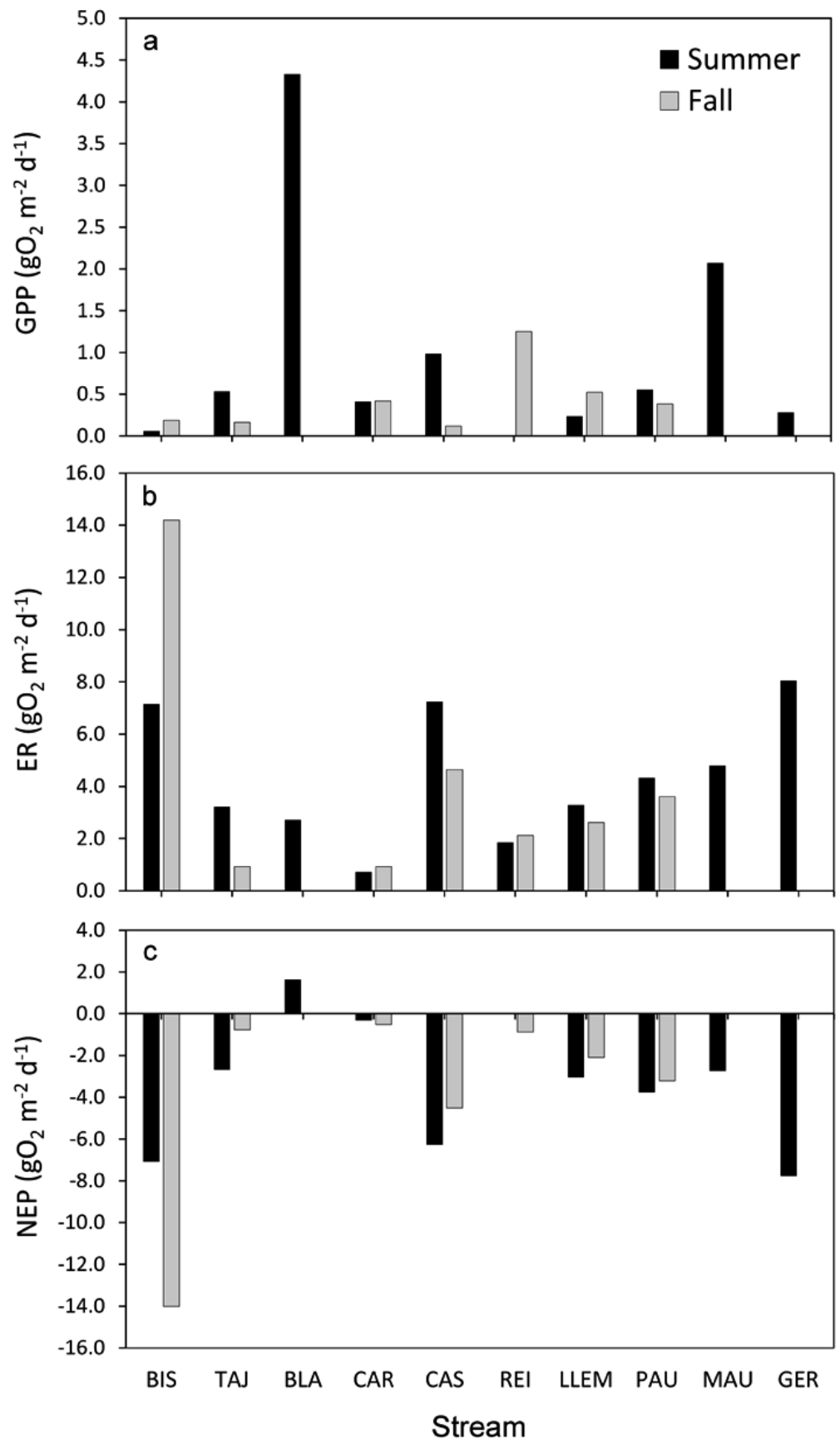

Figure 2. Daily rate of (a) gross primary production (GPP), (b) ecosystem respiration (ER) and (c) net ecosystem production (NEP) in the ten headwaters stream reaches during summer (black bars) and fall (grey bars). Tasa diaria de (a) la producción primaria bruta $(P P B),(b)$ la respiración ecosistémica $(R E)$ y (c) la producción neta del ecosistema (NEP) de los diez tramos fluviales de cabecera estudiados en verano (barras negras) y otoño (barras grises). 
When sites are grouped in regions, the climatic features MAP and MAT, and stream discharge were the variables presenting a stronger variation among regions. MAP was lower for the ICF (500-600 mm) compared to EBF and PCMF (900-1200 mm), while MAT was higher for MF (13-16 $\left.{ }^{\circ} \mathrm{C}\right)$ than for EBF $\left(10-13{ }^{\circ} \mathrm{C}\right)$ and PCMF $\left(9^{\circ} \mathrm{C}\right)$. Finally, stream discharge was higher for the EBF (3.8-5.5 L/s) than for ICF (9.1-24.9 L/s) and PCMF (14.1-30.8 L/s) regions.

The change in the local characteristics between summer and fall did not present a consistent pattern across sites (Table 2). Accordingly, there were no significant differences in regional or local variables between periods (in all cases: paired t-test, $\mathrm{Z}>\mathrm{Z}_{0.05}, p>0.05$ ), except for water temperature and the descriptors of precedent conditions, ADP and T30d, which were higher in summer than in fall (in all cases: paired t-test, $\left.\mathrm{Z}<\mathrm{Z}_{0.05}, p<0.01\right)$.

\section{Variability of stream metabolism}

Across all stream reaches, daily GPP rates varied from 0.06 to $4.33 \mathrm{~g} \mathrm{O}_{2} \mathrm{~m}^{-2} \mathrm{~d}^{-1}$, yet most of reaches exhibited extremely low GPP rates $(<1 \mathrm{~g}$ $\mathrm{O}_{2} \mathrm{~m}^{-2} \mathrm{~d}^{-1}$; Fig. 2a). Between periods, TAJ and CAS had 3-fold higher GPP in summer than in
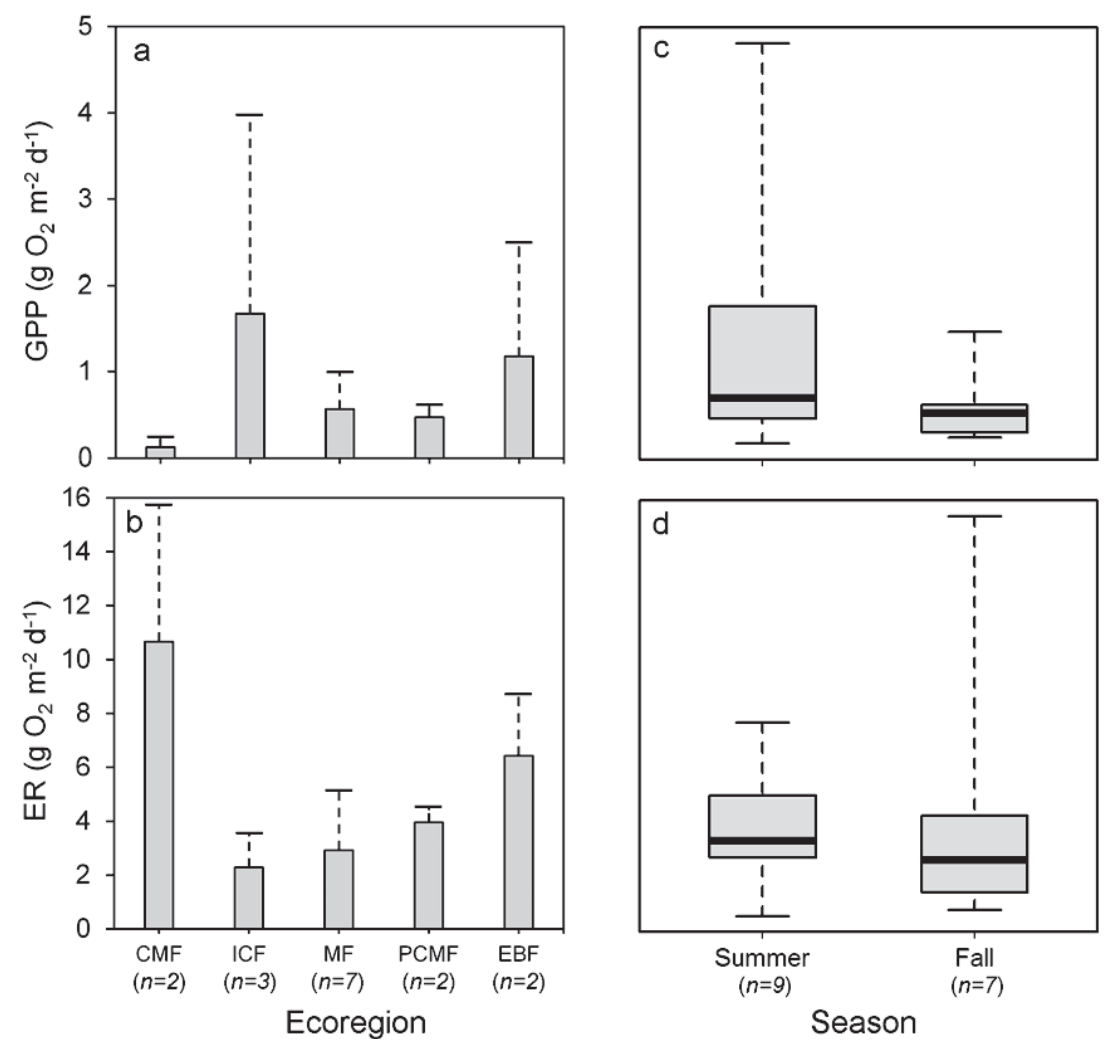

Figure 3. Daily rates of gross primary production (GPP) and ecosystem respiration (ER) averaged across ecoregions (panels (a) and (b), respectively) and between periods (panels (c), and (d), respectively). Bars and discontinuous lines in (a) and (b) denote mean and ranges, respectively. Boxplots in (c) and (d) are for the 25th, 50th and 75th percentiles; whiskers display minimum and maximum values. $\mathrm{CMF}=$ Cantabrian mixed forest, $\mathrm{ICF}=$ Iberian conifer forest, $\mathrm{MF}=$ Mediterranean forest, $\mathrm{PCMF}=\mathrm{Pyrenees}$ conifer and mixed forest and EBF = European broad-leaf forest. Tasas diarias de producción primaria bruta (PPB) y respiración ecosistémica $(R E)$ por ecorregiones (paneles $(a)$ y (b), respectivamente) y entre períodos (panel ( $c$ ), y (d), respectivamente). Las barras y las líneas discontinuas en (a) y (b) muestran los valores de la media y el error estándar (SE), respectivamente. El diagrama de cajas en (c) y (d) muestran los percentiles 25, 50 y 75; los bigotes muestran los valores máximos y mínimos. CMF = bosque mixto Cantábrico, ICF = bosque de coníferas de la Península Ibérica, $M F=$ bosque Mediterráneo, PCMF = bosque mixto y coníferas Pirenaicas y EBF = bosque latifoliado europeo. 
fall, while BIS and LLEM showed the opposite pattern. Daily ER rates ranged from 0.7 to $14.2 \mathrm{~g}$ $\mathrm{O}_{2} \mathrm{~m}^{-2} \mathrm{~d}^{-1}$ (Fig. 2b). TAJ and CAS showed 1.5-fold ER rates in summer than in fall, while ER at the BIS reach was 5-fold higher in fall than in summer. All stream reaches except BLA, which had positive NEP and a $\mathrm{P} / \mathrm{R}$ ratio $>1$, had negative NEP values (median $=-2.9 \mathrm{~g} \mathrm{O}_{2} \mathrm{~m}^{-2}$ $\mathrm{d}^{-1}$ ), indicating net heterotrophic metabolism (Fig. 2c). Within the heterotrophic sites, CAR, REI, and TAJ (in fall) had the highest NEP $\left(>-1.0 \mathrm{~g} \mathrm{O}_{2} \mathrm{~m}^{-2} \mathrm{~d}^{-1}\right)$ and $\mathrm{P} / \mathrm{R}$ ratios $(>0.5)$ while BIS exhibited the lowest $\mathrm{P} / \mathrm{R}$ ratio $(\mathrm{P} / \mathrm{R}$ ratio $=0.01)$. Across all streams, there was no relationship between daily GPP and ER rates (Spearman correlation, $\rho=-0.17, p=0.531$, $n=16)$ neither between GPP and NEP ( $\rho=$ 0.44, $p=0.090, n=16$ ). Conversely, there was a strong correlation between ER and NEP $(\rho=0.96, p<0.001, n=16)$.

Across ecoregions, ICF presented the highest GPP rates, while ER rates were higher for CMF and $\mathrm{EBF}$ than for the other ecoregions (Fig 3a and $3 b$ ). In all regions, daily GPP rates showed higher intra-regional variability than daily ER rates, especially for the ICF and EBF ecoregions, where GPP rates varied between 10 - and 20 -fold across streams (Fig. 3a).

Although there were no significant differences between periods for neither GPP nor ER rates (in both cases: paired t-test, $\mathrm{Z}>\mathrm{Z}_{0.05}, p>0.1$; Fig. 3c and $3 \mathrm{~d}$ ), in both cases mean values were higher in summer. Within sampling periods, metabolic rates were highly variable. For GPP, variability was higher in summer than in fall, while we found the opposite pattern for ER rates.

\section{Regional and local drivers of stream metabolism}

The partial least-square model (PLS) identified distinct regional and local predictors for GPP and ER (Table 4). The PLS model for GPP explained $79 \%$ of the variance (Fig. 4a; Table 4). Except for T30d and ADP, regional variables had low influence on GPP rates (VIP <0.8). Conversely,

Table 4. Summary of partial least square models (PLS) models produced for gross primary productivity (GPP) and ecosystem respiration (ER). Resumen de los resultados de los modelos de regresión de mínimos cuadrados parciales (PLS) para la producción primaria bruta $(P P B)$ y la respiración ecosistémica $(R E)$.

\begin{tabular}{|c|c|c|c|c|c|c|}
\hline & \multicolumn{2}{|c|}{ Regional factors } & \multicolumn{2}{|c|}{ Local factors } & \multirow[t]{2}{*}{$\mathrm{R}^{2} \mathrm{Y}$} & \multirow[t]{2}{*}{$Q^{2} Y$} \\
\hline & & & & & & \\
\hline \multirow{8}{*}{ GPP } & T30d & $0.226 *$ & Coarse:fine & $0.285^{* *}$ & & \\
\hline & $A D P$ & 0.114* & DOC & $0.196 * *$ & & \\
\hline & MAP & -0.143 & Tw & $0.120^{* *}$ & & \\
\hline & Area & 0.017 & Canopy cover & $-0.095^{*}$ & & \\
\hline & MAT & 0.035 & D & $-0.070^{*}$ & & \\
\hline & & & $\mathrm{Q}$ & -0.078 & & \\
\hline & & & $\mathrm{pH}$ & 0.007 & & \\
\hline & & & $\mathrm{EC}$ & 0.107 & 0.79 & 0.32 \\
\hline \multicolumn{7}{|l|}{ ER } \\
\hline & Area & $-0.140 * *$ & EC & $-0.278 * *$ & & \\
\hline & Impacted:Reference & $-0.149 * *$ & Slope & $\mathbf{0 . 0 7 3} * *$ & & \\
\hline & MAP & $0.162 * *$ & pH & $0.087 *$ & & \\
\hline & ADP & 0.188 & Canopy cover & $0.160 *$ & & \\
\hline & MAT & 0.075 & Coarse:Fine & -0.084 & & \\
\hline & P30d & 0.009 & $\mathrm{D}$ & 0.042 & & \\
\hline & & & DIN & -0.134 & 0.81 & 0.68 \\
\hline
\end{tabular}

Values are the coefficients from PLS models which describe the relationship (direction and relative strength) between X- and Y-variables. X-variables included in the PLS models are sorted according to their variable influence on projection value (VIP). Bold font is used to identify the top ones based on their VIP value (VIP > 0.8). Among them, variables with two asterisks in the coeficcients are highly influential (VIP $>1)$ and variables with ones asterisk in the coefficents are the moderately influential ones (VIP between 1 and 0.8 ). See Table 2 for the explanation of the abbreviations. 

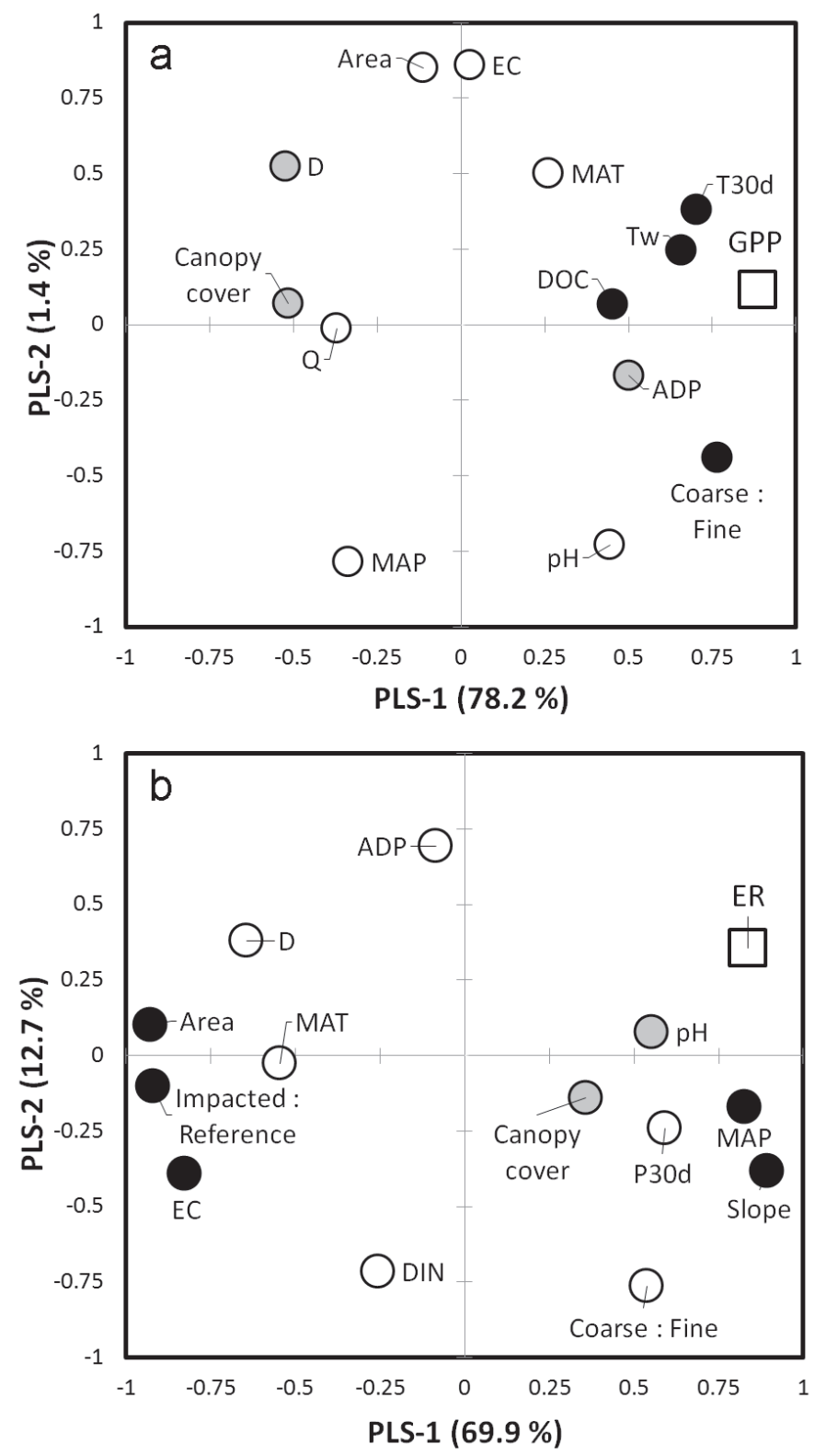

Figure 4. Loadings plot of the PLS regression analysis for (a) gross primary production (GPP) and (b) ecosystem respiration (ER). The graph shows how the Y-variable (squares) correlates with X-variables (circles) and the correlation structure of the X's. X-variables are classified according to their variable influence on projection value (VIP): highly influential (black circles), moderately influential (grey circles) and less influential (white circles). The X-variables situated near Y-variables are positively correlated to them and those situated on the opposite side are negatively correlated. See Table 2 for the explanation of the abbreviations. Representación gráfica de la combinación de variables obtenida en la regresión de mínimos cuadrados parciales (PLS) para (a) la producción primaria bruta $(P P B)$ y (b) la respiración ecosistémica (RE). El gráfico muestra como la variable $Y$ (cuadrados) se correlaciona con la variable $X$ (círculos) y la estructura de correlación de la X. Las variables X están clasificadas según la influencia de la variable en la proyección (VIP): altamente influyente (círculos negros), moderadamente influyente (círculos grises) y poco influyente (círculos blancos). Las variables $X$ situadas cerca de variables Y están positivamente correlacionadas con ellas, mientras que las situadas en el lado opuesto están negativamente correlacionadas. Ver Tabla 2 para ver una explicación detallada de las abreviaciones. 

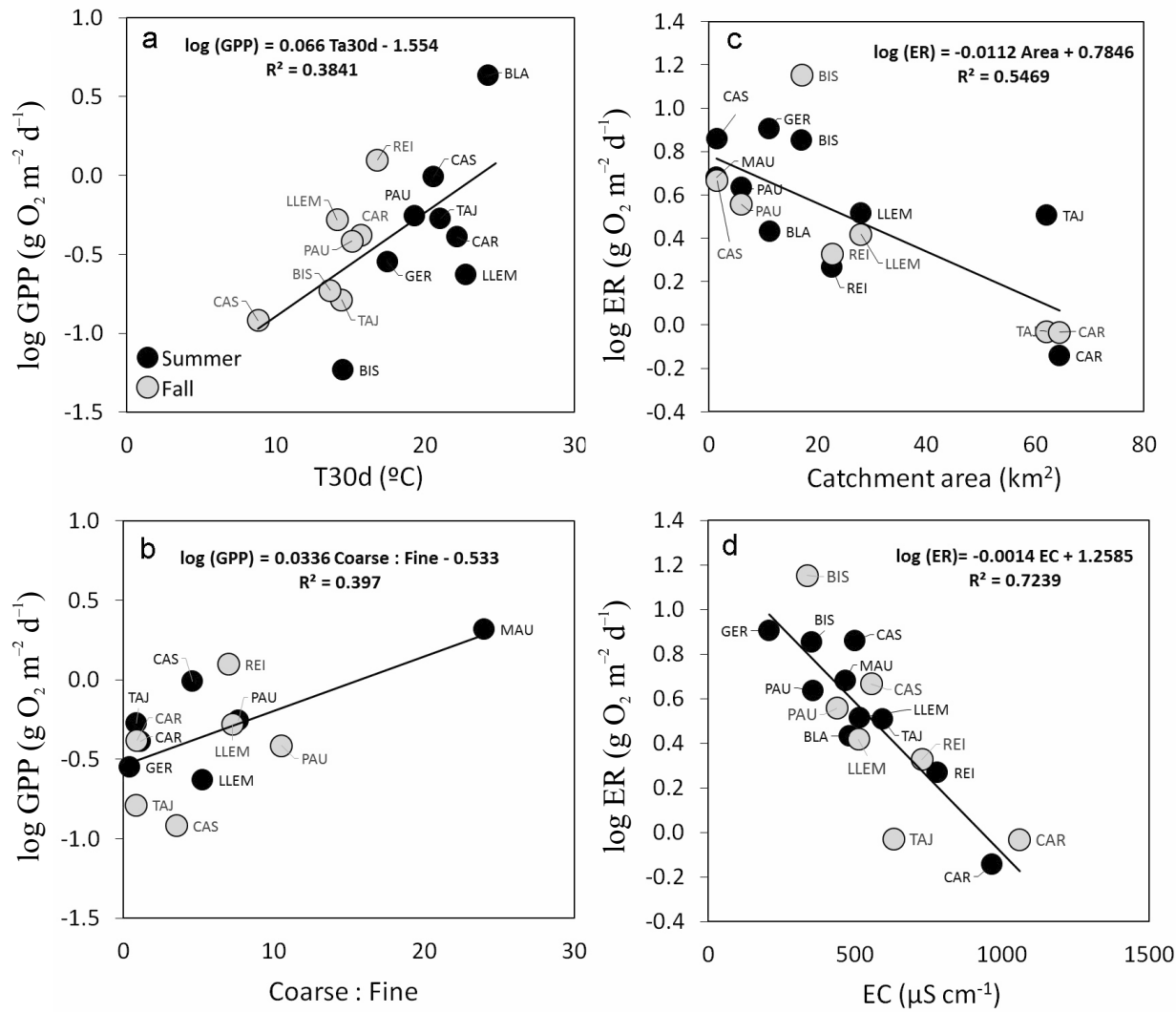

Figure 5. Daily rates of gross primary production (GPP) and ecosystem respiration (ER) for summer (black circles) and fall (grey circles) periods as a function of the regional factors (panels (a) and (c), respectively) and local factors (panels (b) and (d), respectively) that showed the highest VIP values in the PLS models (see Figure 4 and Table 3 for more details). The solid lines represent the model line best fitting the data (i.e., all the observations). Model equations are also shown inside the panels. Tasas diarias de producción primaria bruta (GPP) y respiración ecosistémica (ER) obtenidas en verano (círculos negros) y otoño (círculos grises) en relación a los factores regionales (paneles $(a)$ y (c), respectivamente) y factores locales (paneles $(b)$ y $(d)$, respectivamente) que mostraron los valores VIP más elevados en el modelo PLS (ver Figura 4 y Tabla 4 para más detalles). Las líneas sólidas representan el modelo lineal que mejor se ajusta a los datos (p.ej., todas las observaciones). Las ecuaciones de los modelos se muestran en el interior de los paneles.

among the local variables, the coarse:fine ratio for sediment, Tw and DOC were positively related to GPP, while canopy cover and the mean reach depth had a negative effect on GPP (in all cases: VIP >0.8; Fig. 4a; Table 4; Fig. 5).

The PLS model for ER explained $81 \%$ of the variance (Fig. 4b; Table 4). Three regional variables highly influenced the variance of ER in the studied reaches (VIP $>1.0$ ). Increases in MAP enhanced ER rates, while ER decreased as catchment area and the Impacted:Reference ratio increased. Local factors that highly contributed to explain the variance in ER (VIP > 0.8) were slope, $\mathrm{pH}$, and canopy cover, which were posi- tively related (Fig. 4b; Table 4) and EC which was negatively related, as pointed in Fig. 5.

\section{DISCUSSION}

\section{Stream metabolism across ecoregions and between sampling periods}

The metabolic rates of the studied streams fall in the range of those reported in a recent worldwide review including 215 headwater streams (Hoellein et al., 2013). Moreover, most of the studied streams were heterotrophic and did not show 
any relationship between GPP and ER rates, supporting the general paradigm that metabolism in headwater streams mainly relies on organic inputs from the terrestrial ecosystem (Hoellein et al., 2013; Vannote, 1980).

According to our expectations, GPP presented the highest values in the warm and dry region of ICF, while ER rates were the highest in the humid regions CMF and EBF. However, differences across ecoregions are weakened by a very high variability within regions. Although our study is pioneer comparing metabolic rates across south European climates, similar trends have been previously identified in North America. For instance, Mulholland et al., (2001) found differences in metabolic rates when comparing individual reaches of seven ecoregions, yet this pattern was less evident when included several streams for each region (Bernot et al., 2010; Dodds et al., 2015). The strong variability in stream metabolism within ecoregions might suggest that apart from the climate and biogeography, other regional (i.e geology, land cover; Bernot et al. 2010) and local variables (see discussion below) are determining the metabolic processes. In order to be able to predict metabolic processes as a function of the ecoregion, future studies need to complete the number of streams in the different regions, especially for those regions such as the arid and the humid Mediterranean regions, typically underrepresented in the literature.

The measured metabolic rates presented no significant differences between sampling periods, yet the mean values of GPP and ER were higher in summer than in fall. In Mediterranean regions, storm flows (i.e. high discharge after precipitation events) can promote a massive transport of nutrients and organic matter from the catchment to the streams (Bernal et al., 2013), and therefore, we expected an increase of metabolic rates in fall (Acuña et al., 2004; Crenshaw et al., 2002). The lack of significant differences between summer and fall might be explained by the absence of statistical differences in flow conditions or past precipitation between time periods. However, it is worth pointing out that the high variability in ER during fall might reflect heteroge- neous increases of the terrestrial inputs reaching the streams across sites (Fig. 3d).

On the other hand, variables such as temperature or canopy cover might spread heterogeneity on GPP during summer (Fig. 3b). Indeed, the relative importance of seasonality and geographical distribution might be site-dependent, modulated by the topography and land uses of each watershed, which hampers our interpretation at the regional scale. Taken together, a further evaluation of the influence of other local and regional variables is apparent and will be discussed hereafter.

\section{Drivers of headwater stream metabolism}

GPP was mainly controlled by local drivers, specifically those that are known to favour the activity of the autotrophic community. We found that changes in both air and water temperature, as well as the weather-related variable ADP, notably affected GPP rates, which agree with previous studies showing that warming has a positive effect on metabolic rates (Carpenter et al., 1992; Yvon-Durocher et al., 2012). Moreover, light availability has been shown to be one of the main drivers of spatial and temporal variations in GPP rates (Bernot et al., 2010; Lupon et al. 2016). Accordingly, canopy cover and stream depth (proxies of light availability in the streambed) were selected in the PLS model as variables with negative influence on GPP rates. In agreement, the most autotrophic stream (i.e. the southern stream BLA) not only presented the highest temperature among the sampled streams, but also the lowest canopy cover and depth. In fact, BLA was an exceptional high productivity stream, with NEP values around the $90^{\text {th }}$ percentile reported for worldwide streams (Hoellein et al., 2013). Similar daily values have been observed in southern Spain in summer (Mollá et al., 1994), suggesting that southern Iberian Peninsula area can hold high stream productivity comparable to those found in the arid regions with little riparian vegetation (Bernot et al., 2010; Busch \& Fisher, 1981).

Our results also support the well-established idea that streambed substrate and water biogeochemistry can influence stream metabolic activity (Bott et al., 2006). Coarse substrates can 
enhance GPP and ER rates across streams by providing a suitable substrate that facilitates the development of autotrophic biofilm (Aristegi et al., 2010; Clapcott \& Barmuta, 2010; Johnson \& Tank, 2009), the vertical hydrological exchange, and the hyporheic respiration (Jones, Fisher \& Grimm, 1995; Fellows et al. 2001; Ingendahl et al., 2009). In our study, streambed substrate was not related to ER, suggesting that our streams had either low vertical water exchange or reduced hyporheic extension (Ingendahl et al., 2009). Conversely, rocks and sands enhanced algal primary production because coarse:fine ratio was selected as highly influential variable with positive coefficient for the GPP model. Moreover, we found a positive relation between DOC and GPP, which is in agreement with previous studies that reported peaks in DOC concentrations associated with blooms of benthic algae (Royer et al., 2005). However, further information on the quality of DOC, rather than only considering the bulk concentrations of DOC, is required to better understand this relationship (Mullholand et al. 2003).

In the case of ER, regional drivers seemed to be as good predictors as local factors. MAP, for example, explained ER better than snapshot values of discharge or morphology, supporting the fact that the variation of ER may be partially regulated by regional climate. Indeed, the ICF region had lower MAP than the northern regions (CMF, IBF and PCMF) and MF presented a high intra-region MAP variability. The significance of the relationship between ER and precipitation regimes is a topic of intense debate, and indeed, previous studies have not found a clear effect of precipitation on ER across regions when analysed by categorical units (Bernot et al., 2010; Dodds et al., 2015). Wet climates are associated to high productive lush, deciduous vegetation (Olson et al., 2001), which might increase the amount of organic matter in the forest soils compared to arid climates. Moreover, the studied wet catchments hold hilly slopes, and thus, terrestrial organic matter might eventually reach the stream and fuel in-stream respiration. This later idea is supported by the positive effect of canopy cover on ER, and suggests that future changes in catchment vegetation induced by variations in
MAP may potentially affect metabolic activity in headwater streams of southern Europe.

Other variables classified as regional, such as catchment area and the Impacted:Reference ratio were also involved in the regulation of ER. Despite the fact that large catchments are usually associated to high ER rates due to a higher drainage of nutrients and carbon (Hoellein et al., 2013; Howarth \& Sherman, 1991), we found a negative relationship between ER rates and catchment area. This fact may be associated to the strong influence of impacted land uses on ER, as the lowest ER was found in catchments holding agriculture and urban uses. In fact, these two variables, together with the slope of the reach, were strongly correlated to each other (See Table S3, available at www.limnetica.com), suggesting an intimate co-variation between watershed size and their land uses. Therefore, pristine-like streams usually drain water from steep, small watersheds with low human impacts; while stream reaches situated on the valleys receive water from larger basins that are more influenced by anthropogenic activities.

Moreover, ER varied in response of water conductivity and $\mathrm{pH}$. This relationship might reflect the negative effects of human impacts (e.g. mining activities, urbanization) on ER as they are proxies of point and non-point anthropogenic sources into streams (Paul \& Meyer, 2001; Von Schiller et al., 2008, Cañedo-Argüelles et al. 2016). Indeed, both EC and $\mathrm{pH}$ were highly correlated with the ratio of impacted to reference land use proportion in the watershed (Table S3); further indicating a strong negative influence of human activities on stream ER rates. However, it is worth noticing that ER might not show a linear relationship at higher impact intensity than the range comprised by our study. In particular, high ER rates might be associated to poor healthy streams due to inputs of organic waste and nutrients (reviewed in Young et al., 2008). Therefore, although the discussion of the application of metabolism metric for stream health categorization and management purposes is beyond our scope, this study suggests that the use of ER as functional indicator of river health should be yet interpreted with caution for low 
impacted streams. Further research in this topic is necessary previous the application of metabolic rates as indicators of ecosystem health.

\section{CONCLUSIONS}

This is the first study where a network of young researchers conducted a coordinated distributed experiment using an easy, inexpensive methodology and exemplifies the successful use of this kind of research to accomplish complex ecological goals at large geographical scales. Our results pinpoint a trend in metabolic processes, with GPP and ER being the highest in the driest and most humid regions, respectively. Furthermore, regional-scale variables are important for explaining metabolism, especially ER. This process was mostly determined by climatic drivers as well as by the degree of human impacts holding the watershed, while GPP was mostly determined by drivers directly affecting the stream autotrophic community, such as temperature, light availability and streambed substrate. These differences among regions generated a strong variability in the seasonal pattern of metabolic processes, hampering the identification of a clear pattern between sampling period linked to changes in hydrology and terrestrial inputs. However, further research is needed in order to fully understand how spatial and temporal changes in climatic conditions may affect stream metabolism.

\section{AUTHORS CONTRIBUTION}

A. Pastor and N. Catalán conceived and designed the study. A. Lupon, L. Gómez-Gener and T. Rodríguez-Castillo analyzed and interpreted the data with inputs from AP and NC. E. Estévez provided the GIS data. A. Lupon, L. Gómez-Gener, T. Rodríguez, A. Pastor and N. Catalán drafted the manuscript. All the co-authors performed field campaigns, acquired data, and contributed to the final version of the manuscript.

\section{ACKNOWLEDGMENTS}

We thank the support of the AIL board throughout the development of the project and all the affiliated institutions for the accessibility of laboratory premises, especially the Limnology Department of Uppsala University and the Department d'Ecologia of the Universitat de Barcelona. We greatly thank all the extended team of participants for their valuable contribution in DOMIPEX project. The authors were supported by the following founding: NC by Wenner-Gren foundation stipend (Sweden, 2014-2016) and a Juan de la Cierva grant (FJCI-2014-23064), EE by a pre-doctoral grant from the Basque Government (2014-2017), AGB by a Swedish Research Council grant (SMAREF 2014-2016), PRL by a Ramón Areces Foundation Postdoctoral Scholarship AM by the Univ. of the Basque Country, AMGF and SP by pre-doctoral research grants from the Spanish Ministry of Economy and Competitiveness (Ref: BES-2013-065770, Ref: BES-2012-059743, respectively), and RR by the IMDEA-Water Institute. DOMIPEX project was founded by the First Call of Collaborative Projects among Young Researchers of the Iberian Association of Limnology (AIL; 2013-2015).

\section{REFERENCES}

ACUÑA, V., A. GIORGI, I. MUÑOZ, U. UEHLINGER \& S. SABATER. 2004. Flow extremes and benthic organic matter shape the metabolism of a headwater Mediterranean stream. Freshwater Biology, 49: 960-971.

ARISTEGI, L., O. IZAGIRRE \& A. ELOSEGI. 2010. Metabolism of Basque streams measured with incubation chambers, Limnetica, 29: 301-310.

BATTIN, T.J., L.A. KAPLAN, S. FINDLAY, C.S. HOPKINSON, E. MARTI, A.I. PACKMAN, J.D. NEWBOLD \& F. SABATER. 2009. Biophysical controls on organic carbon fluxes in fluvial networks. Nature Geoscience, 2: 595-595.

BENSON, B.B. \& D. KRAUSE. 1984. The concentration and isotopic fractionation of oxygen dis- 
solved in freshwater and seawater in equilibrium with the atmosphere, Limnology and Oceanography, 29: 620-632.

BERNAL, S., D. VON SCHILLER, F. SABATER \& E. MARTÍ. 2013. Hydrological extremes modulate nutrient dynamics in mediterranean climate streams across different spatial scales. Hydrobiologia, 719: 31-42.

BERNOT, M.J., D.J. SOBOTA, R.O. HALL, P.J. MULHOLLAND, W.K. DODDS, J.R. WEBSTER, J.L. TANK, L.R. ASHKENAS, L.W. COOPER, C.N. DAHM, S.V. GREGORY, N.B. GRIMM, S.K. HAMILTON, S.L. JOHNSON, W.H. MCDOWELL, J.L. MEYER, B. PETERSON, G. POOLE, H.M. VALETT, C. ARANGO, J.J. BEAULIEAU, A.J. BURGIN, C. CRENSHAW, A.M. HELTON, L. JOHNSON, J. MERRIAM, B.R. NIEDERLEHNER, J.M. O'BRIEN, J.D. POTTER, R.W. SHEIBLEY, S.M. THOMAS, K. WILSON. 2010. Inter-regional comparison of land-use effects on stream metabolism. Freshwater Biology, 55: 1874-1890.

BOTT, T.L. 2006. Primary productivity and community respiration. In F. R. Lamberti \& G. A. Hauer (Eds.), Methods in Stream Ecology (pp. 663-690). San Diego: Academic Press.

BOTT, T.L., J.D. NEWBOLD \& D.B. ARSCOTT. 2006. Ecosystem Metabolism in Piedmont Streams: Reach Geomorphology Modulates the Influence of Riparian Vegetation. Ecosystems, 9: 398-421.

BURROWS, R.M., E.R. HOTCHKISS, M. JONSSON, H. LAUDON, B.G. MCKIE \& R.A. SPONSELLER. 2015. Nitrogen limitation of heterotrophic biofilms in boreal streams. Freshwater Biology, 1-15.

BUSCH, D.E. \& S.G. FISHER. 1981. Metabolism of a Desert Stream. Freshwater Biology, 11: 301307.

CARPENTER, S.R., S.G. FISHER, N.B. GRIMM \& J.F. KITCHELL. 1992. Global chnage and freshwater ecosystems. Annual Review of Ecological Systems, 23: 119-139.

CLAPCOTT, J.E. \& L.A. BARMUTA. 2010. Metabolic patch dynamics in small headwater streams: exploring spatial and temporal variability in benthic processes. Freshwater Biology, 55: 806-824.

COLE, J.J. \& N.F. CARACO. 2001. Carbon in catchments: Connecting terrestrial carbon losses with aquatic metabolism. Marine and Freshwater Research, 52: 101-110.
CRENSHAW, C.L., H.M. VALETT \& J.R. WEBSTER. 2002. Effects of augmentation of coarse particulate organic matter on metabolism and nutrient retention in hyporheic sediments. Freshwater Biology, 47: 1820-1831.

DEMARS, B. O.L., J.R. MANSON, J.S. ÓLAFSON, G.M. GÍSLASON, R. GUDMUNDSDÓTTIR, G. WOODWARD, J. REISS, D.E. PICHLER, J.J. RASMUSSEN \& N. FRIBERG. 2011. Temperature and the metabolic balance of streams . Freshwater Biology, 56: 1106-1121.

DENICOLA, D.M. 1996. Periphyton responses to temperature at different ecological levels. Algal Ecology: Freshwater Benthic Ecosystems. Elsevier Inc.

DODDS, W.K., K. GIDO, M.R. WHILES \& M.D. DANIELS. 2015. The Stream Biome Gradient Concept: factors controlling lotic systems across broad biogeographic scales. Freshwater Science, 34: 1-19.

ERIKSSON, L., E. JOHANSSON, N. KETTANEHWOLD, J.TRYGG, C. WISKTRÖM \& S. WOLD. 2006. Multi- and megavariate data analysis. Part I basic principles and applications. Second revised and enlarged edition. Umetrics AB.

FIELD, C.B., V.R. BARROS, K.J. MACH, M.D. MASTRANDREA, M. VAN AALST, W.N. ADGER, D.J. ARENT, J. BARNETT, R. BETTS, T.E. BILIR, J. BIRKMANN, J. CARMIN, D.D. CHADEE, A.J. CHALLINOR, M. CHATTERJEE, W. CRAMER, D.J. DAVIDSON, Y.O. ESTRADA, J.-P. GATTUSO, Y. HIJIOKA, O. HOEGH-GULDBERG, H.Q. HUANG, G.E. INSAROV, R.N. JONES, R.S. KOVATS, P. ROMERO-LANKAO, J.N. LARSEN, I.J. LOSADA, J.A. MARENGO, R.F. MCLEAN, L.O. MEARNS, R. MECHLER, J.F. MORTON, I. NIANG, T. OKI, J.M. OLWOCH, M. OPONDO, E.S. POLOCZANSKA, H.-O. PÖRTNER, M.H. REDSTEER, A. REISINGER, A. REVI, D.N. SCHMIDT, M.R. SHAW, W. SOLECKI, D.A. STONE, J.M.R. STONE, K.M. STRZEPEK, A.G. SUAREZ, P. TSCHAKERT, R. VALENTINI, S. VICUÑA, A. VILLAMIZAR, K.E. VINCENT, R. WARREN, L.L. WHITE, T.J. WILBANKS, P.P. WONG \& G.W. YOHE. 2014. Technical summary. In: Climate Change 2014: Impacts, Adaptation, and Vulnerability. Part A: Global and Sectoral Aspects. Contribution of Working Group II to the Fifth Assessment Report of the Intergovernmental Panel on Climate Change. Field, C.B., V.R. Barros, D.J. Dokken, K.J. Mach, M.D. Mastrandrea, T.E. Bilir, 
M. Chatterjee, K.L. Ebi, Y.O. Estrada, R.C. Genova, B. Girma, E.S. Kissel, A.N. Levy, S. MacCracken, P.R. Mastrandrea, and L.L. White (eds.): 35-94. Cambridge University Press, Cambridge, United Kingdom and New York, NY, USA.

FISHER, S.G. \& G.E. LIKENS. 1973. Energy flow in Bear Brook, New Hampshire: an integrative approach to stream ecosystem metabolism. Ecological Monographs, 43: 421-439.

FRASER, L.H., H. AL HENRY, C.N. CARLYLE, S.R. WHITE, C. BEIERKUHNLEIN, J.F. CAHILL, B.B. CASPER, E. CLELAND, S.L. COLLINS, J.S. DUKES, A.K. KNAPP, E. LIND, R. LONG, Y. LUO, P.B. REICH, M.D. SMITH, M. STERNBERG \& R. TURKINGTON. 2013. Coordinated distributed experiments: An emerging tool for testing global hypotheses in ecology and environmental science. Frontiers in Ecology and the Environment, 11: 147-155.

GORDON, N.D., T.A. MCMAHON, B.L. FINLAYSON, C.J. GIPPEL \& R.J. NATHAN. 2004. Stream hydrology: an introduction for ecologists. (John Wiley \& Sons, Ed.) (2nd edition). Wiley.

GRIMM, N.B. \& S.G. FISHER. 1986. Nitrogen limitation in a Sonoran Desert stream. Journal of the North American Benthological Society, 5: 2-15.

GUASCH, H., E. MARTÍ \& S. SABATER. 1995. Nutrient enrichment effects on biofilm metabolism in a Mediterranean stream. Freshwater Biology, 33(3): 373-383.

HOELLEIN, T.J., D.A. BRUESEWITZ \& D.C. RICHARDSON. 2013. Revisiting Odum (1956): A synthesis of aquatic ecosystem metabolism. Limnology and Oceanography, 58: 2089-2100.

HOTCHKISS, E.R., R.O. HALL JR, R.A. SPONSELLER, D. BUTMAN, J. KLAMINDER, H. LAUDON, M. ROSVALL \& J. KARLSSON. 2015. Sources of and processes controlling $\mathrm{CO}_{2}$ emissions change with the size of streams and rivers. Nature Geoscience, 8: 696-699.

HOWARTH, R.W., J.R. FRUCI \& D. SHERMAN. 1991. Inputs of sediment and carbon to an estuarine ecosystem: influence of land use. Ecological Applications, 1: 27-39.

JOHNSON, L.T. \& J.L. TANK. 2009. Diurnal variations in dissolved organic matter and ammonium uptake in six open-canopy streams. Journal of the North American Benthological Society, 28: 694708.

JONES, J.B., S.G. FISHER \& N.B. GRIMM. 1995. Vertical hydrologic exchange and ecosystem meta- bolism in a Sonoran desert stream. Ecology, 76: 942-952.

KNAPP, A.K. \& M.D. SMITH. 2001. Variation among biomes in temporal dynamics of aboveground primary production. Science, 291: 481-484.

LUPON, A., E. MARTÍ, F. SABATER \& S. BERNAL. 2016. Green light: gross primary production influences seasonal stream $\mathrm{N}$ export by controlling fine-scale N dynamics. Ecology, 97: 133-144.

MOLLÁ, S., L. MALTCHIK \& C. CASADO. 1994. Primeros datos sobre el metabolismo de un arroyo temporal mediterráneo en Sierra Morena (Córdoba). Limnetica, 10: 59-67.

MULHOLLAND, P.J. 2003. Large-scale patterns in dissolved organic carbon concentration, flux, and sources. In Aquatic ecosystems: interactivity of dissolved organic matter: 139-159. Elsevier.

MULHOLLAND, P.J., C.S. FELLOWS, J.L. TANK, N.B. GRIMM, J.R. WEBSTER, S.K. HAMILTON, E. MARTÍ, L. ASHKENAS, W.B. BOWDEN, W.K. DODDS, W.H. MCDOWELL, M.J. PAUL \& B.J. PETERSON. 2001. Inter-biome comparison of factors controlling stream metabolism. Freshwater Biology, 46: 1503-1517.

MULHOLLAND, P.J., E.R. MARZOLF, J.R. WEBSTER, D.R. HART, S.P. HENDRICKS \& H.B. STATION. 1997. Evidence that hyporheic zones increase heterotrophic metabolism and phosphorus uptake in forest streams. Limnology and Oceanography, 42: 443-451.

MUNNÉ, A., N. PRAT, C. SOLÀ, N. BONADA \& M. RIERADEVALL. 2003. A simple field method for assessing the ecological quality of riparian habitat in rivers and streams: QBR index. Aquatic Conservation: Marine and Freshwater Ecosystems, 13: 147-163.

ODUM, H.T. (1956). Primary production in flowing waters. Limnology and Oceanography, 1(2): 102117.

OLSON, D.M., E. DINERSTEIN, E.D. WIKRAMANAYAKE, N.D. BURGESS, G.V.N. POWELL, E.C. UNDERWOOD, J.A. D'AMICO, I. ITOUA, H.E. STRAND, J.C. MORRISON, C.J. LOUCKS, T.F. ALLNUTT, T.H. RICKETTS, Y. KURA, J.F. LAMOREUX, W.W. WETTENGEL, P. HEDAO \& K.R. KASSEM. 2001. Terrestrial ecoregions of the world: A new map of life on earth. BioScience, 51: 933.

PARDO, I., M. ÁlVAREZ, J. CASAS, J.L. MORENO, S. VIVAS, N. BONADA, J. ALBA-TERCEDOR, P. JÁIMEZ-CUÉLLAR, G. MOYÀ, N. 
PRAT, S. ROBLES, M.L. SUÁREZ, M. TORO, D.E. UNIVERSIDAD, D.V. CAMPUS \& I. PARDO. 2004. El hábitat de los ríos mediterráneos. Diseño de un índice de diversidad de hábitat. Limnetica, 21: 115-133.

PAUL, M.J. \& J.L. MEYER. 2001. Sreams in the urban landscape. Annual Review of Ecological Systems, 32: 333-365.

RAYMOND, P.A., J. HARTMANN, R. LAUERWALD, S. SOBEK, C. MCDONALD, M. HOOVER, D. BUTMAN, R.G. STRIEGL, E. MAYORGA, C. HUMBORG, P. KORTELAINEN, H. DÜRR, M. MEYBECK, P. CIAIS \& P. GUTH. 2013. Global carbon dioxide emissions from inland waters. Nature, 503: 355-9.

RAYMOND, P.A., C.J. ZAPPA, D. BUTMAN, T.L. BOTT, J. POTTER, P. MULHOLLAND, A.E. LAURSEN, W.H. MCDOWELL \& D. NEWBOLD. 2012. Scaling the gas transfer velocity and hydraulic geometry in streams and small rivers. Limnology and Oceanography: Fluids \& Environments, 2: 41-53.

REARDON, J., J.A. FOREMAN \& R.L. SEARCY. 1966. New reactants for the colorimetric determination of ammonia. Clinical Chimica Acta, 14: 403-405.

ROBERTS, B.J., P.J. MULHOLLAND \& W.R. HILL. 2007. Multiple scales of temporal variability in ecosystem metabolism rates: results from 2 years of continuous monitoring in a forested headwater stream. Ecosystems, 10: 588-606.

ROYER, T.V. \& M.B. DAVID. 2005. Export of dissolved organic carbon from agricultural streams in Illinois, USA. Aquatic Sciences, 67: 465-471.

SCHLESINGER, W.H. 2009. On the fate of anthropogenic nitrogen. Proceedings of the National Academy of Sciences of the United States of America, 106: 203-8.

SINSABAUGH, R.L. 1997. Large-Scale Trends for Stream Benthic Respiration. Journal of the North American Benthological Society, 16: 119-122.

SORANNO, P.A., K.S. CHERUVELIL, E.G. BISSELL, M.T. BREMIGAN, J.A. DOWNING, C.E.
FERGUS, C.T. FILSTRUP, E.N. HENRY, N.R. LOTTIG, E.H. STANLEY, C.A. STOW, P. TAN, T. WAGNER \& K.E. WEBSTER. 2014. Crossscale interactions: quantifying multi- scaled cause-effect relationships in macrosystems. Frontiers in Ecology and the Environment, 12: 65-73.

TANK, J.J.L., E.J.E. ROSI-MARSHALL, N.A. GRIFFITHS, S.A. ENTREKIN \& M.L. STEPHEN. 2010. A review of allochthonous organic matter dynamics and metabolism in streams. Journal of the North American Benthological Society, 29: 118-146.

VANNOTE, R.L., G.W. MINSHALL, K.W. CUMMINS, J.R. SEDELL \& C.E. CUSHING. 1980. The River Continuum Concept. Canadian Journal of Fisheries and Aquatic Sciences, 37: 130-137.

VON SCHILLER, D., E. MARTÍ, J.L. RIERA, M. RIBOT, J.C. MARKS \& F. SABATER. 2008. Influence of land use on stream ecosystem function in a Mediterranean catchment. Freshwater Biology, 53: 2600-2612.

WEBSTER, J.R. \& J.L. MEYER. 1997. Organic matter budgets for streams: a synthesis. Journal of the North American Benthological Society, 16: 141-161. WOODWARD, G., N. BONADA, L.E. BROWN, R.G. DEATH, I. DURANCE, C. GRAY, S. HLADYZ, M.E. LEDGER, A.M. MILNER, S.J. ORMEROD, R.M. THOMPSON \& S. PAWAR. 2016. The effects of climatic fluctuations and extreme events on running water ecosystems. Philosophical Transactions of the Royal Society B, 371: 20150274.

YOUNG, R.G., C.D. MATTHAEI \& C.R. TOWNSEND. 2008. Organic matter breakdown and ecosystem metabolism: functional indicators for assessing river ecosystem health. Journal of the North American Benthological Society, 27: 605-625.

YVON-DUROCHER, G., J.M. CAFFREY, A. CESCATTI, M. DOSSENA, P. DEL GIORGIO, J.M. GASOL, J.M. MONTOYA, J. PUMPANEN, P.A. STAEHR, M. TRIMMER, G. WOODWARD \& A.P. ALLEN. 2012. Reconciling the temperature dependence of respiration across timescales and ecosystem types. Nature, 487: 472-476. 